\title{
The Efficacy of the Retirement Pension Provision System: Modeling, and Assessing of the Case of Kazakhstan
}

\author{
Gulsara Ashirbayevna Junusbekova * and Marzhan Dosymovna Zhaumitova \\ Institute of Management, Academy of Public Administration under the President of the Republic of Kazakhstan, \\ Nur-Sultan 010000, Kazakhstan; m.zhaumitova@apa.kz \\ * Correspondence: g.dzhunusbekova@apa.kz
}

Received: 15 October 2020; Accepted: 14 November 2020; Published: 18 November 2020

\begin{abstract}
This research is aimed at developing a methodology for assessing the efficacy of a macroeconomic model of the Kazakhstani pension provision system. A hierarchy of indicators of the pension system efficacy is built using the graph method. The representativeness of these indicators is confirmed by using expert assessment and factor analysis. A multi-factor assessment model is built using an additive convolution of the normalized values of the 2014-2019 resulting indicators with a breakdown by regions, regarding the coefficients of their significance. A regression model is developed to show the dependence of the pension system efficacy on the share of the accumulative system in the structure of retirement scheme financing. The optimal part of the accumulative system amounting to $79.5 \%$ of the total system is determined to be the level at which the pension system efficiency is maximized. A neural model for predicting the pension system efficacy under the influence of labor market indicators is built. The size of the minimum required annual payroll deductions from the wages of persons working according to the accumulative system is calculated depending on the length of service; this minimum size ensures a replacement rate of $40 \%$ with regard to the optimal ratio of the accumulative and solidarity pension systems. These findings will be useful to state bodies when developing and clarifying directions for reforming the pension system in Kazakhstan.
\end{abstract}

Keywords: Kazakhstan; pension system; labor market; accumulative pension model; solidarity pension model; pension fund; social insurance; pensioners

\section{Introduction}

Pension schemes are one of the social issues that is constantly a major focus for governments in any country [1-4]. The Republic of Kazakhstan is no exception. The current pension system of Kazakhstan has functioned since 1997, when the concept of reforming the pension system was adopted [5]. Proceeding from the set goals, Kazakhstan used the Chilean retirement plan model as the basis for its pension reform process [6]. This model assumes fixed contributions on individual pension accounts and the accumulation of individual contributions in the state budget, which subsequently becomes a source of pension payments. Starting on 1 January 1998, the entire working population of the country had to make mandatory contributions at the rate of $10 \%$ of monthly income to an individual account in the accumulative pension fund [7]. After the next stage of pension reform in 2013, all pension funds which existed at that time in the country were merged into the Unified Accumulative Pension Fund (UAPF) Joint Stock Company [8]. These radical changes ensured the formation of a three-tier Kazakhstani Pension System, including an accumulative component (voluntary and mandatory pension contributions) and a solidarity component in the form of guaranteed pension payments from the republic's budget (which provides the main level of support). The accumulative 
component makes it possible to overcome the risks associated with population senescence and the consequent increased pension payments that would otherwise be required from the state budget [9]. The solidarity component in the form of guaranteed pension payments from the budget also provides major support.

Seemingly, the current Pension System of Kazakhstan is ready for future demographic trends. However, it should be noted that despite its three-tier structure, retirement pension payments only represent two components (payments from the state budget and payments from the UAPF) because of the underdevelopment of voluntary employee contributions to the UAPF JSC or to private financial organizations [10]. At the same time, the state budget of the Republic plays an overwhelming role in pension payments, accounting for about $20 \%$ of Republican budget expenditures [11] and 3.3\% of Kazakhstan's GDP at the beginning of 2020 [12]. Thus, for example, the share of UAPF contributions amounted to only $6.3 \%$ of total pension payments as of 2019 and is constantly decreasing [12], while budget pension expenditures are growing too quickly, outstripping high inflation levels in Kazakhstan by two or three times [12]. The replacement rate in Kazakhstan has remained unchanged since 2013 , not exceeding $45 \%$ on average, whereas it averages $70 \%$ in developed countries [13]. Kazakhstan has already crossed the line of the initial senescence level, and by 2050, almost every fifth citizen of Kazakhstan will be over 60 years of age, while the trend of a steady decline in the birth rate and increased life expectancy will continue in the country [14]. This, in turn, will exert even greater pressure on the country's budget and create the risk of a decreased replacement rate.

The level of recorded pension payments from the budget is guaranteed by the State and depends on the labor market development, growth of tax payments, and other budget revenues. There is an extensive shadow economy in Kazakhstan, which includes not only evasion of official registrations but also unreported income from the production of legal goods and services, either from monetary or barter transactions. These problems apply equally to both the solidarity (paid from the State budget) and the accumulative pension systems (paid for by the UAPF). An excessively high proportion of people with low incomes in the labor market is another big problem for the pension system in Kazakhstan. About half of the employed population of Kazakhstan receives wages of less than 112.2 thousand tenge [15] - the median wage value at the end of 2019. The average wage was 203.9 thousand tenge in the country in 2019 [15], which is around twice the median wage value (throughout 2019, the weighted average exchange rate of Kazakhstan's national currency was set as follows: 1 EUR $=428.63$ KZT [16]). The wider the gap between average and median wages, the higher the proportion of workers with low wages. Therefore, the pension payments made remain relatively low.

Based on best practices $[9,17,18]$, most of a decent future pension ultimately consists of individual pension payments, while state payments are provided only as a guaranteed minimum pension level for the unprotected segments of the population. Therefore, according to the Concept for Further Modernization of the Pension System of the Republic of Kazakhstan until 2030 [19], the pension reform is long-term in nature, and a complete transition to the accumulative pension system is expected be completed by $2038-2040$.

However, it should be noted that when developing plans to reform the pension system, it is necessary to consider that pension payments are made at the expense of the future results of economic activities. The choice of suitable reform options, in particular for a pension system, must necessarily consider the specifics of a particular country, and available factors that facilitate or impede the successful implementation of reforms, such as the level of labor market development. However, in this context, it is necessary to highlight two dimensions of the problem. The first is discussions about the problems of the labor market, about the level of poverty of the population in general and the elderly in particular, and about stratification in Kazakhstan. The second is the very structure of the pension system, and its efficacy. This research is aimed at establishing the efficacy of the reforming and functioning of the current pension system in Kazakhstan. This study contributes to science in terms of providing a deep understanding of the importance of the baseline in defining the potential scale and boundaries of pension provision. It allows determining the pace and scope of a viable reform, though assessing the 
pension system in relation to all structural components is also required depending on the results that need to be obtained during the reform.

\section{Literature Review}

In economics, the adequacy of pension provision to guarantee the material well-being of people of retirement age has ceased to be the only criterion for assessing the pension system [20]. Regarding current demographic trends, the discussion of pension system efficacy is also gaining importance [21-24]. Today, efficacy is also a fundamental criterion for improving pension system reform, based on a comparative analysis of retirement plan models in different countries $[6,7,25]$ and adequately assessing the practical experience of their functioning [2-4]. It is rather difficult to find a definition of the concept of the pension system efficacy in the literary sources. An analysis of the scientific literature indicates two dimensions in approaches to assess the efficacy of pension provision: efficiency both at the macroeconomic level $[21,22,26,27]$ and at the economic agent level (micro level) $[21,23,24,28]$.

Theories of consumption and savings [29,30] and the theory of permanent income [31-33] have laid the foundation for evaluating the efficiency of pension provision. Since pension system efficacy at the macroeconomic level requires the maximization of consumer utility throughout the life of an economic entity [34], it can be argued that at the microeconomic level, pension system efficacy can be assessed in terms of the rate of return, that is by assessing the ratio between the level of pension payments and the level of the economic agent's contributions. In the classic sense, efficacy in this case involves the excess of the indexation of pension payments by the state of the internal rate of return (real yield of pension payments). However, life annuity is of crucial importance for people who are retired [28]. In this case, it can be asserted that the pension system efficacy on a microeconomic scale is commensurate with the level of adequacy of pension payments for economic agents. The higher the level of the efficacy, the more adequate the level of pension payments.

From a macroeconomic level viewpoint, the nature of the pension system efficacy is different and implies that the pension mechanism is a tool for the redistribution of current GDP between generations: between those who work and those who have already retired [26,35]. A distinctive feature of the pension system efficacy at the macroeconomic level is revealed in the assessment of the influence of smoothing the consumption of one economic agent on that of another one, and, in general, on the overall distribution of GDP $[22,26,27]$. In this case, the pension system efficacy will be manifested in the leveling of the negative impact on the labor market development, economic activity in the economy, etc. under the influence of modern trends in demographic transformation. Consequently, from this point of view, pension system efficacy can be assessed by the ratio of the funding provided to pensioners as pensions and the costs that the working generation faces from supporting this pension funding. Within the framework of this article, the macroeconomic aspect of the pension system efficacy was used as the basis for the research.

Traditionally, two conceptual approaches have been used for providing pension payments. The first assumes the functioning of the solidarity mechanism, which is based on the aggregate payroll deductions of the working-age population, assuming compulsory participation in insurance against the risk of senescence (a solidarity pension system) [7]. The second approach is based on the functioning of an accumulative mechanism, which assumes individual financing of the pension by the employee himself at the expense of a share of wages and investment income (accumulative pension system) [18]. As demonstrated by the world experience [36], conceptually, most scholars [7,21,37,38] tend to believe that the highest level of the efficacy of social guarantees for pensioners is achieved by creating a multi-tier pension system and by simultaneous operation of both models of the pension system. The symbiosis of basic public pension provision, solidarity, and accumulative components forms a stable basis for a balanced pension provision. This practice is actively used by many countries [36], but with the prevailing dominance of the accumulative component in the pension system. This is explained by the fact that countries in which pension provision is based on compulsory payments from the working-age population face the problem of an excess of the number of pensioners over 
the number of working people over time [39]. With the increase in the difference between these two groups, the obligations of the state increase in direct proportion.

Also, in the opinion of some scholars [2,9,40,41], an accumulative pension system and voluntary individual contributions in particular should become a full-fledged basis for the formation of pensions, as there is no more effective instrument for pension provision in practice. However, as already noted, an effective pension system, with appropriate fiscal possibilities, should contain elements that provide a guarantee of a basic level of social security in old age for all persons who had a low level of income during their life or had little work experience in the formal sector of the economy $[7,38]$. Therefore, with a variety of approaches to the efficacy of the pension system formation and its reform, the component structure may be different. However, a proper balance is needed between the structural elements of the system, as well as an understanding that the development of components depends on specific conditions and circumstances.

\section{Methods and Materials}

\subsection{Data}

The list of statistical indicators that characterize the efficacy of the pension system of the Republic of Kazakhstan was formed based on an analysis of the literature [21-24] and confirmed using the methods of factor analysis [42,43] and expert assessment [44,45]. The list of these indicators includes a replacement rate indicating the ratio of the pension and previous income/earnings of a pension recipient (Replac), a coverage coefficient determining the part of the population covered by the pension system (Cover), and a load factor determining the part of pension recipients in the total number of the insured population (Load). It also comprises the indicator of the ratio of the average monthly pension to the subsistence minimum (Pens), the indicator of the growth rate of the average nominal pension (Nom_Pens_GR), the indicator of the growth rate of the average real pension (Real_Pens_GR), and the indicator of the ratio of the received wages of all employed persons to the amount of pension paid to all pension recipients $(\mathrm{Wag})$. In addition, the required parameters indicate the rate of monthly pension deductions from the employee's total income (Rate), the regularity of contributions to the Unified Accumulative Pension Fund of the Republic of Kazakhstan (UAPF) (Regul), coverage of the population contributing to the UAPF (Cover_Accum), the average period of pension payment-the difference between average life expectancy and retirement age (Term), and rate of profit on pension savings (Prof).

According to the methodology of the World Bank [46] and techniques proposed in [13,47,48], when assessing the pension system efficacy, replacement rates (Replac), coverage (Cover), and load (Load) coefficients are widely used. The replacement rate is considered as an indicator of the ratio of the pension to the previous income/earnings of the pension recipient. The inexpediency of using this indicator in assessing the pension system efficacy is conditioned by the fact that the pension system in Kazakhstan is in the process of reforming, which began in 1998 and continues until now in terms of the development and improvement of the accumulative system. In this context, comparison of payments with payroll deductions that have a significant time lag does not provide an adequate assessment of the efficacy of both the current and the previous pension system. In its essence, the Replac indicator is reflected through the Wag indicator. The Wag indicator enables us to correlate the size of paid pensions in the $i$-th period and the size of the deduction base (wages) in the $i$-th period, at the expense of which pension payments are made. Thus, this indicator allows for a current assessment of the efficacy, with regard to the retirement burden at the time of assessment.

Indicators Cover and Load also characterize the workload in physical terms. The indicator Wag reflects the ratios that are assessed when calculating these coefficients, though only in value terms. The indicator Wag characterizes the economic effect reflected by the indicators Replac, Cover, and Load based on the ratio of pension income and expenses, and not just the number of pensioners, excluding the standards of mandatory and voluntary contributions. 
The ratio of the average monthly pension to the subsistence minimum (Pens) characterizes the pensioners' standard of living. The indicator Pens depends on the size of the base of pension payments for solidarity and accumulative systems, which in turn is determined by the replacement rate (Replac), coefficients of coverage (Cover, Cover_Accum) and load (Load), the ratio of received wages to the amount pension paid (Wag), the rate of monthly pension deductions (Rate), the regularity of contributions to the UAPF (Regul), the timing of pension payments (Term), and the rate of profit on pension savings (Prof). On the other hand, the ratio of the received wages to the amount of the pension paid (Wag) depends on the pension size with the inverse nature of the dependence.

The growth rate of the average nominal pension (Nom_Pens_GR) and the growth rate of the average real pension (Real_Pens_GR) depend on the same indicators as Pens. In turn, indicators of the dynamics of pension payments exert an impact on the level of pensioners' income (Pens). The relationship between the indicators Nom_Pens_GR and Real_Pens_GR is reflected in the fact that the real pension dynamics is determined by the nominal pension dynamics, adjusted for the inflation rate in the country.

Further use of the pension system efficacy indicators in modeling the interdependent system will lead to multicollinearity of the model and a decreased accuracy of the estimation results. This made it necessary to structure the aforementioned indicators for the purpose of identifying the resulting indicators that reflect the influence of others. The graph method was used to structure the indicators. The implementation of the method for this study involved building an oriented graph based on nodes and edges. Performance indicators of the pension system were used as nodes. The edges of the graph were characterized by the dependencies between the performance indicators. The levels of the hierarchy of indicators were determined empirically based on the results of the construction of the pension system involving: (1) The set of attainability $\left(S_{i}\right)$-the graph vertices (indicators) to which there is a path from the $i$-th indicator; $(2)$ the set of predecessor vertices $\left(P_{i}\right)$-the vertices that lead to the $i$-th indicator. The first level of the hierarchy was formed by indicators for which the equality $P_{i}=S_{i} \cap P_{i}$ is fulfilled. At the second iteration, the indicators that formed the first level of the hierarchy were excluded, after which the fulfillment of the equality $P_{i}=S_{i} \cap P_{i}$ was re-checked. According to the results of two iterations, all investigated indicators were attributed to a certain level of hierarchy. The indicators that formed the 2nd level of the hierarchy were used to build the model for assessing the effectiveness of the pension system. These indicators became the result and reflected the impact of the 1 st level of the hierarchy.

To assess the Kazakhstani pension system efficacy, the annual values of the resulting indicators by region/city for the period 2014-2019 were used, according to [10,15]. These data represent a homogeneous array, as evidenced by the coefficients of variation not exceeding $10 \%$. The representativeness of the sample of indicators was confirmed by the cumulative percentage of variance being $88.7 \%$, (factor analysis was performed using Statistica 12.0 software). The period of research was chosen in the context of a reform of the pension system of Kazakhstan that occurred in 2013, which resulted in the new structure of the pension system that currently exists. This is the maximum period of operation of the current pension system, so the paper assesses the effectiveness of this system during that period. Studying the experience of the previous system does not make sense because of the ineffectiveness of the previous pension framework.

The results of the statistical assessment, which were obtained using factor analysis, were confirmed by using expert assessments. For this, a group of 40 people representing the UAPF of Kazakhstan with at least 5 years of experience in the field of pension provision was formed. The experts were asked to assess: (1) the feasibility of using each of the indicators when assessing the pension system efficacy; and (2) the sufficiency of the proposed indicators for completeness of the pension system efficacy assessment [49] on a 5-point scale. The feasibility of using these indicators was confirmed by expert assessments. The feasibility of using Pens indicator was estimated to be $100 \%$, Nom_Pens_GR was estimated to be $89 \%$ (by 178 points out of 200 maximum), Real_Pens_GR was estimated to be $98.5 \%$ (by 197 points out of 200 maximum points), and Wag was estimated to be $97.5 \%$ (by 195 points out of 200 maximum). The sufficiency of the proposed list of indicators was estimated was estimated 
to be $97.5 \%$. The degree of consistency of expert opinions, when assessed using the coefficient of variation, did not exceed $2.87 \%$ when assessing the feasibility of indicators, and amounted to $3.07 \%$ when assessing the sufficiency of the proposed list of indicators. The values of the variation indicators, not exceeding $10 \%$, indicated the consistency of expert opinions on the representativeness of the indicators Pens, Nom_Pens_GR, Real_Pens_GR, and Wag while assessing the pension system's efficacy in the Republic of Kazakhstan.

\subsection{Methods}

The integral indicator of the efficacy was built on the basis of an additive convolution of the normalized values of the pension system efficacy indicators, regarding their significance coefficients $(w)$. Significance coefficients were determined using a system of formulas:

$$
\begin{gathered}
w_{i}=\left(w_{d i} \times w_{e i}\right) / \sum_{i=1}^{n}\left(w_{d i} \times w_{e i}\right) \\
w_{e i}=b_{i} / \sum_{i=1}^{n} b_{i} \\
n=4
\end{gathered}
$$

where $w_{i}$ is a significance coefficient of the $i$-th indicator when assessing the efficacy of the pension system;

$w_{d i}$ is a coefficient of statistical significance of the $i$-th indicator corresponding to variance percentage of the $i$-th factor, provided that each factor consists of one statistically significant indicator. The significance of the indicators was determined based on the factor loadings of the indicators and the corresponding factors. Factor loadings $>|0.75|$ were accepted to be significant [42];

$w_{e i}$ is an expert coefficient of statistical significance of the $i$-th indicator that was determined as a result of expert assessment;

$b_{i}$ is the sum of points (for an expert group) characterizing the feasibility of using the $i$-th indicator when assessing the efficacy of the pension system.

Then $I=\sum_{i=1}^{n}\left(w_{i} \times \overline{X_{i}}\right)$, where $I$ is an integral indicator of the pension system efficacy, and $\overline{X_{i}}$ is a normalized value of the $i$-th indicator.

It was proposed to assess the efficiency of the solidarity and accumulative pension systems by determining the dependence of the integral indicator of the efficacy $(I)$ on the share of solidarity and accumulative pension systembin the structure of pension payments. The adequacy of the constructed model was confirmed by the excess of the empirical value of the F-criterion (104.1) over the tabular value (3.96) at $p=0.05$.

The state of the labor market is the main factor affecting the efficiency of the pension system [50-53]. Therefore, the indicators of the labor market for 2014-2019 were used as independent variables affecting the forecast indicators of the Kazakhstani pension system efficacy in the context of regions and cities in the Republic of Kazakhstan in line with [15].

To predict the efficacy in the Statistica 12.0 software, a neural network was built, the dependent variable of which was the efficacy indicator $(I)$, and independent variables are labor market indicators; other major factors included the growth rate of the economically active population in units (EAP_GR), the growth rate of the employed population, in units (Empl_GR), the growth rate of the unemployed population, in units (Unempl_GR), the employment level, in shares $\left(E m p l \_R\right)$, and the growth rate of real wages, in units (Real_Wage_GR).

The statistical significance of the impact of indicators $E A P \_G R, E m p l \_G R, U n e m p l \_G R, E m p l \_R$, and Real_Wage_G on the pension system efficiency at a significance level of $p=0.05$ was proved by the constructed neural network involving: the percentage of deviation of the dependent variable values calculated by the model from the actual values; the level of educational, control, and test errors. 
There is no statistically significant relationship between $E A P_{-} G R, E m p l \_G R, U n e m p l \_G R, E m p l \_R$, and Real_Wage_G, thereby indicating the absence of multicollinearity in the model.

When using a neural network, the deviation of the calculated values from the actual ones was $1.7 \%$, while this deviation amounted to $16.3 \%$ when using a linear regression model and $7.9 \%$ when using a vector autoregressive model $-7.9 \%$.

\section{Results}

A graph depicting causal relations between the indicators of the pension system efficacy was built based on a theoretical analysis of the relationship between these indicators (Figure 1). The graph was used to determine the levels in the hierarchy of indicators of the Kazakhstani pension system efficacy (Table 1).

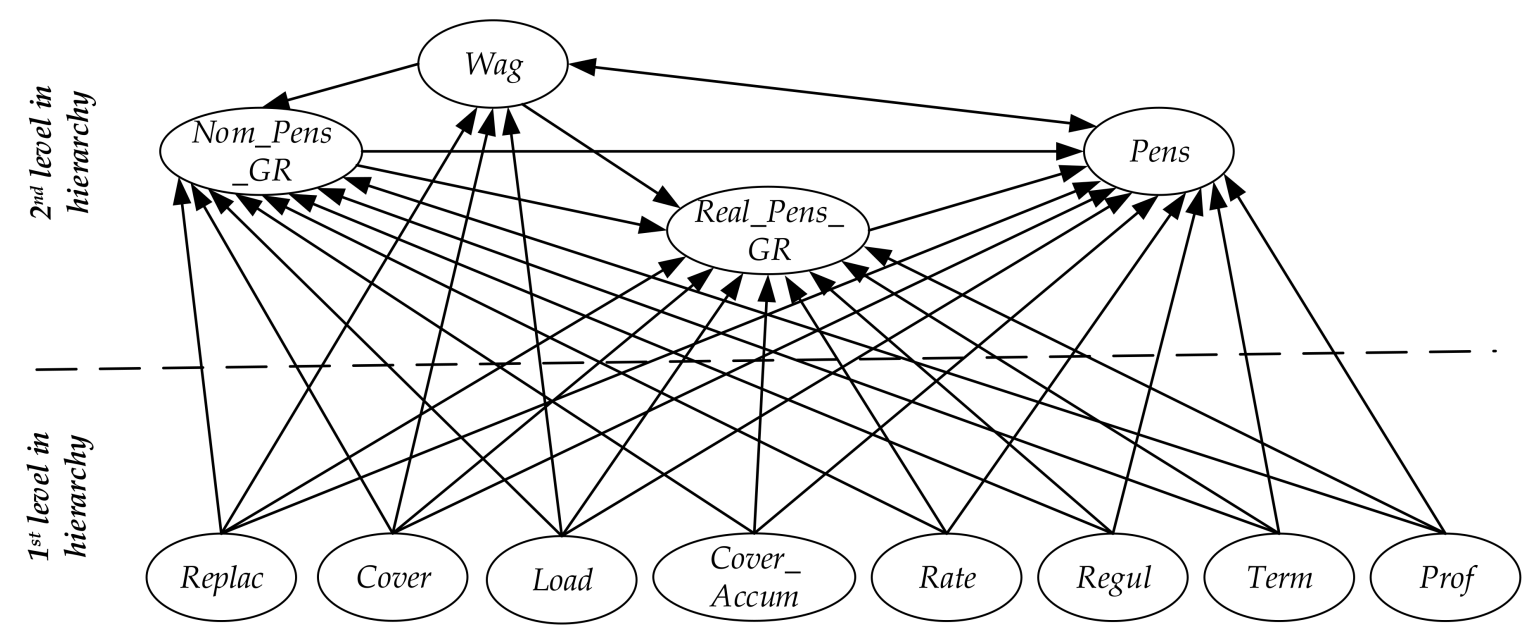

Figure 1. A graph of causal relations between the indicators of the pension system efficacy.

Table 1. Levels in the hierarchy of indicators of the pension system efficacy.

\begin{tabular}{|c|c|c|c|c|}
\hline$i$ & $S_{i}$ & $P_{i}$ & $S_{i} \cap P_{i}$ & Hierarchy Level \\
\hline \multicolumn{5}{|c|}{ 1st iteration } \\
\hline Replac & $\begin{array}{l}\text { Replac,Pens, } \\
\text { Nom_Pens_GR, } \\
\text { Real_Pens_GR, Wag }\end{array}$ & Replac & Replac & 1 \\
\hline Cover & $\begin{array}{l}\text { Cover, Pens, } \\
\text { Nom_Pens_GR, } \\
\text { Real_Pens_GR, Wag }\end{array}$ & Cover & Cover & 1 \\
\hline Load & $\begin{array}{l}\text { Load,Pens, } \\
\text { Nom_Pens_GR, } \\
\text { Real_Pens_GR, Wag }\end{array}$ & Load & Load & 1 \\
\hline Pens & $\begin{array}{l}\text { Pens, } \\
\text { Nom_Pens_GR, } \\
\text { Real_Pens_GR, Wag }\end{array}$ & $\begin{array}{l}\text { Pens, Replac, Cover, Load, } \\
\text { Nom_Pens_GR, Real_Pens_GR, Wag, } \\
\text { Rate, Regul, Cover_Accum,Term, Prof }\end{array}$ & $\begin{array}{l}\text { Pens, Nom_Pens_GR, } \\
\text { Real_Pens_GR,Wag }\end{array}$ & - \\
\hline Nom_Pens_GR & $\begin{array}{l}\text { Nom_Pens_GR, } \\
\text { Pens, Real_Pens_GR, } \\
\text { Wag }\end{array}$ & $\begin{array}{l}\text { Nom_Pens_GR, Replac, Cover, Load, } \\
\text { Pens, Real_Pens_GR, Wag, Rate, Regul, } \\
\text { Cover_Accum,Term, Prof }\end{array}$ & $\begin{array}{l}\text { Nom_Pens_GR, Pens, } \\
\text { Real_Pens_GR, Wag }\end{array}$ & - \\
\hline Real_Pens_GR & $\begin{array}{l}\text { Real_Pens_GR, Pens, } \\
\text { Nom_Pens_GR, Wag }\end{array}$ & $\begin{array}{l}\text { Real_Pens_GR, Replac, Cover, Load, } \\
\text { Pens, Nom_Pens_GR, Wag, Rate, Regul, } \\
\text { Cover_Accum,Term, Prof }\end{array}$ & $\begin{array}{l}\text { Real_Pens_GR, Pens, } \\
\text { Nom_Pens_GR, Wag }\end{array}$ & - \\
\hline Wag & $\begin{array}{l}\text { Wag, Pens, } \\
\text { Nom_Pens_GR, } \\
\text { Real_Pens_GR }\end{array}$ & $\begin{array}{l}\text { Wag, Replac, Cover, Load, Pens, } \\
\text { Nom_Pens_GR, Real_Pens_GR, Rate, } \\
\text { Regul, Cover_Accum,Term,Prof }\end{array}$ & $\begin{array}{l}\text { Wag, Pens, } \\
\text { Nom_Pens_GR, } \\
\text { Real_Pens_GR }\end{array}$ & - \\
\hline
\end{tabular}


Table 1. Cont.

\begin{tabular}{|c|c|c|c|c|}
\hline$i$ & $S_{i}$ & $P_{i}$ & $\overline{S_{i} \cap \boldsymbol{P}_{i}}$ & Hierarchy Level \\
\hline Rate & $\begin{array}{l}\text { Rate,Pens, } \\
\text { Nom_Pens_GR, } \\
\text { Real_Pens_GR }\end{array}$ & Rate & Rate & 1 \\
\hline Regul & $\begin{array}{l}\text { Regul,Pens, } \\
\text { Nom_Pens_GR, } \\
\text { Real_Pens_GR }\end{array}$ & Regul & Regul & 1 \\
\hline Cover_Accum & $\begin{array}{l}\text { Cover_Accum, Pens, } \\
\text { Nom_Pens_GR, } \\
\text { Real_Pens_GR }\end{array}$ & Cover_Accum & Cover_Accum & 1 \\
\hline Term & $\begin{array}{l}\text { Term,Pens, } \\
\text { Nom_Pens_GR, } \\
\text { Real_Pens_GR }\end{array}$ & Term & Term & 1 \\
\hline Prof & $\begin{array}{l}\text { Prof, Pens, } \\
\text { Nom_Pens_GR, } \\
\text { Real_Pens_GR }\end{array}$ & Prof & Prof & 1 \\
\hline \multicolumn{5}{|c|}{ 2nd iteration } \\
\hline Pens & $\begin{array}{l}\text { Pens, } \\
\text { Nom_Pens_GR, } \\
\text { Real_Pens_GR, Wag }\end{array}$ & $\begin{array}{l}\text { Pens, Nom_Pens_GR, } \\
\text { Real_Pens_GR, Wag }\end{array}$ & $\begin{array}{l}\text { Pens, Nom_Pens_GR, } \\
\text { Real_Pens_GR, Wag }\end{array}$ & 2 \\
\hline Nom_Pens_GR & $\begin{array}{l}\text { Nom_Pens_GR, } \\
\text { Pens, Real_Pens_GR, } \\
\text { Wag }\end{array}$ & $\begin{array}{l}\text { Nom_Pens_GR, Pens, } \\
\text { Real_Pens_GR, Wag }\end{array}$ & $\begin{array}{l}\text { Nom_Pens_GR, Pens, } \\
\text { Real_Pens_GR, Wag }\end{array}$ & 2 \\
\hline Real_Pens_GR & $\begin{array}{l}\text { Real_Pens_GR,Pens, } \\
\text { Nom_Pens_GR, Wag }\end{array}$ & $\begin{array}{l}\text { Real_Pens_GR,Pens, } \\
\text { Nom_Pens_GR, Wag }\end{array}$ & $\begin{array}{l}\text { Real_Pens_GR, Pens, } \\
\text { Nom_Pens_GR, Wag }\end{array}$ & 2 \\
\hline Wag & $\begin{array}{l}\text { Wag, Pens, } \\
\text { Nom_Pens_GR, } \\
\text { Real_Pens_GR }\end{array}$ & $\begin{array}{l}\text { Wag, Pens, Nom_Pens_GR, } \\
\text { Real_Pens_GR }\end{array}$ & $\begin{array}{l}\text { Wag, Pens, } \\
\text { Nom_Pens_GR, } \\
\text { Real_Pens_GR }\end{array}$ & 2 \\
\hline
\end{tabular}

Note: $i$-indicator; $S\left(z_{i}\right)$ —a set of attainability; $P\left(z_{i}\right)$-a set of preceding vertices.

The efficacy of a pension system is ensured by having a high standard of pensioners' standard of living in conjunction with a minimum pension burden on workers, which was confirmed by the results of determining the hierarchy of indicators. The indicators that formed the 2 nd level of the hierarchy include the ratio of the average monthly pension to the minimum subsistence level (Pens), the growth rate of the average nominal pension (Nom_Pens_GR), the growth rate of the average real pension (Real_Pens_GR), and the indicator of the ratio of the received wages of all employed persons to the amount of pension paid to all pension recipients (Wag). These indicators are resultant ones, which reflect the influence of indicators of the 1st level in the hierarchy. Therefore, they were used to assess the efficacy of the pension system in Kazakhstan.

The system of indicators was designed in such a way as to reflect the living standard of pensioners, provided by pension payments, and the burden on workers by comparing the amount of pensions paid with the size of employees' average wages (the deduction base). The use of the wage indicator was conditioned by the fact that its size influences the amount of deductions to the UAPF and the amount of the individual income tax paid, which is one of the sources forming the revenue part of the Republican budget, which provides pension payments according to the solidarity system.

The factor structure of the pension system efficacy and coefficients of significance of indicators, corresponding to the factor variance percentage were determined using factor loadings (Table 2).

The cumulative factorization percentage of $88.7 \%$ (exceeding $80 \%$ [42]) is a statistical confirmation that the proposed list of indicators is representative and sufficient to describe the Kazakhstani pension system efficacy. The coefficients of significance of indicators $\left(w_{d}\right)$ correspond to the factor variance percentage with which indicators Pens, Nom_Pens_GR, Real_Pens_GR, and Wag have significant factor loadings. The coefficients of significance of the indicators made $w_{d P e n s}=0.268, w_{d N_{\text {Nom_Pens_GR }}}=0.168$, $w_{d R e a l \_P e n s_{-} G R}=0.204, w_{d W a g}=0.247$. The disadvantage of this approach to determining the relative significance of indicators is that the factor analysis technology does not provide for the presence of a dependent variable. The calculated variance percentages show for how many percent each of the factors (indicators) explains the change in the system described using these indicators. The representativeness 
of the indicators Pens, Nom_Pens_GR, Real_Pens_GR, Wag when assessing the pension system efficacy and expert assessments for the coefficients of the significance $\left(w_{e}\right)$ of indicators when building an integral model of the pension system efficacy is indicated in Table 3.

Table 2. Factor loadings of the Kazakhstani pension system efficacy indicators.

\begin{tabular}{ccccc}
\hline \multirow{2}{*}{ Indicator } & \multicolumn{3}{c}{ Factor } \\
\cline { 2 - 5 } & F1 & F2 & F3 & F4 \\
\hline Pens & $0.91^{*}$ & -0.21 & 0.07 & 0.24 \\
\hline Nom_Pens_GR & 0.47 & 0.33 & 0.51 & $0.81^{*}$ \\
\hline Real_Pens_GR & 0.29 & 0.13 & $0.88^{*}$ & 0.35 \\
\hline Wag & -0.40 & $0.90 *$ & 0.31 & 0.16 \\
\hline Factor variance percentage, $\%$ & 26.8 & 24.7 & 20.4 & 16.8 \\
\hline
\end{tabular}

Note: ${ }^{*}$ marks the significant factor loadings of indicators $(>|0.75|)$.

Table 3. Coefficients of the relative significance of indicators in the integral model for assessing the Kazakhstani pension system efficacy.

\begin{tabular}{ccccc}
\hline Coefficients of the Relative & \multicolumn{4}{c}{ Indicator } \\
\cline { 2 - 5 } Significance of Indicators & Pens & Nom_Pens_GR & Real_Pens_GR & Wag \\
\hline$w_{d}$ & 0.268 & 0.168 & 0.204 & 0.247 \\
\hline$w_{e}$ & 0.260 & 0.231 & 0.256 & 0.253 \\
\hline$w$ & 0.312 & 0.174 & 0.234 & 0.280 \\
\hline
\end{tabular}

The results of expert assessments show that indicator Pens is the most significant indicator in assessing the pension system efficacy; its relative significance is 0.260 . The significance of the indicators was assessed as follows: Real_Pens_GR $=0.256, W a g=0.253$, Nom_Pens_GR $=0.231$. All indicators have a direct impact on the pension system efficacy. Taking into account the variance percentage and expert assessments, the coefficients of significance $(w)$ were calculated using Formula (1). According to them, Pens ( $w_{\text {Pens }}=0.312$ ) was the most influential indicator; its priority was proven by the results of factor analysis and expert assessment. The coefficients of the relative significance of other indicators were: $w_{\text {Nom_Pens_GR }}=0.174, w_{\text {Real_Pens_GR }}=0.234, w_{\text {Wag }}=0.280$.

Regarding the weighting factors, the model for assessing the pension system efficacy can be written as:

$$
I=0.312 \times \overline{\text { Pens }}+0.174 \times \overline{\text { Nom_Pens_GR }}+0.234 \times \overline{\text { Real_Pens_GR }}+0.280 \times \overline{\text { Wag }}
$$

Based on the normalized values of indicators and their coefficients of significance, an integral assessment of the pension system efficacy was obtained across the regions (Table 4).

Indicators Pens, Nom_Pens_GR, Real_Pens_GR, Wag are stimulants; therefore, an increase in I indicates an increase in the efficacy. According to the results obtained, the Atyrau Region, East Kazakhstan Region, Nur-Sultan (Astana until 2019), and Almaty cities demonstrate the highest efficacy of the pension system during 2014-2019. Of these, the Atyrau Region, Nur-Sultan, and Almaty cities have the highest percentages of pension payments in Kazakhstan owing to the accumulative system: $27.6 \%, 24.6 \%, 19.0 \%$, respectively, with an average national percentage of $11.9 \%$ for the period of 2014-2019. The Kyzylorda, Jambyl, and North Kazakhstan Regions showed the lowest efficacy of the pension system, with the accumulative system not exceeding $8 \%$ in the pension provision structure in these regions. 
Table 4. Values of the integral assessment of the pension system efficacy as broken down by regions/cities of Kazakhstan (I).

\begin{tabular}{lcccccc}
\hline \multirow{2}{*}{ Region/City } & \multicolumn{6}{c}{ Period } \\
\cline { 2 - 7 } & $\mathbf{2 0 1 4}$ & $\mathbf{2 0 1 5}$ & $\mathbf{2 0 1 6}$ & $\mathbf{2 0 1 7}$ & $\mathbf{2 0 1 8}$ & $\mathbf{2 0 1 9}$ \\
\hline Akmola Region & -0.183 & 0.039 & -0.134 & -0.213 & -0.208 & 0.228 \\
\hline Aktobe Region & 0.395 & 0.143 & -0.122 & 0.232 & -0.076 & 0.220 \\
\hline Almaty Region & -0.492 & -0.355 & -0.196 & -0.081 & -0.173 & 0.038 \\
\hline Atyrau Region & 0.654 & 0.320 & 0.599 & 0.183 & 0.789 & 0.376 \\
\hline West Kazakhstan Region & 0.279 & -0.091 & -0.219 & 0.103 & -0.237 & -0.264 \\
\hline Jambyl Region & -0.406 & -0.166 & -0.219 & -0.231 & -0.138 & -0.208 \\
\hline Karaganda Region & -0.441 & -0.043 & 0.162 & 0.063 & 0.070 & -0.124 \\
\hline Kostanay Region & 0.352 & 0.068 & -0.284 & 0.271 & 0.132 & 0.133 \\
\hline Kyzylorda Region & -0.582 & -0.891 & 0.138 & -1.145 & -0.952 & -0.744 \\
\hline Mangystau Region & 0.481 & -0.094 & 0.199 & 0.693 & -0.160 & -0.095 \\
\hline Pavlodar Region & -0.039 & 0.321 & -0.117 & -0.309 & 0.192 & 0.004 \\
\hline North Kazakhstan Region & -0.403 & -0.016 & -0.168 & -0.563 & -0.094 & -0.132 \\
\hline East Kazakhstan Region & 0.236 & 0.437 & 0.253 & 0.263 & 0.621 & 0.566 \\
\hline Nur-Sultan city & 0.666 & 0.412 & 0.480 & 0.842 & 0.577 & 0.652 \\
\hline Almaty city & 0.004 & 0.426 & 0.308 & 0.500 & 0.465 & 0.567 \\
\hline
\end{tabular}

The relationship between the integral indicator of the pension system efficacy and the shares of accumulative and solidarity systems is described by the function:

$$
I=-2.24 \times r_{a}^{2}+3.56 \times r_{a}-0.43
$$

where $r_{a}$ is part of pension payments made through the accumulative system (from the RK UAPF), expressed in shares.

The polynomial function of dependence of the pension system efficiency indicator on the share of the savings system demonstrates the second stage of the function behavior. At the first stage, the growth of the share of the funded system leads to the growth of the efficiency index. This growth slows down at the maximum point, which corresponds to the maximum possible efficiency of the existing pension system of Kazakhstan at this level of economically active population and employment, and through the dynamics of real wages. Further growth of the share of the savings system leads to a decrease in the efficiency of the pension system. The model has been used to determine the optimal ratio of the funded and solidary pension systems, where the efficiency is aimed at maximizing the efficiency of the existing pension system.

Finding the first-order derivative $I^{\prime}$ enabled us to determine the target value of the accumulative system share in the structure of pension payments, at which the maximum level of the pension system efficacy is achieved $(I=\max )$. When $r_{a}=0.795 I^{\prime}=0, I=\max$. Within the range of values of the indicator $r_{a} \in[0 ; 0.795]$, an increase in the share of the accumulative system promotes an increase in the pension provision efficacy, after which a further increase in the accumulative system share will lead to a decrease in the overall efficacy due to an increase in the burden on the potential pension recipient. The optimal participation of the state makes $20.5 \%$. We have developed a model for forecasting the effectiveness of the pension system of Kazakhstan under the influence of the state of the labor market; its characteristics are shown in Table 5. 
Table 5. Statistical characteristics of the model for forecasting the Kazakhstani pension system's efficacy.

\begin{tabular}{ccccc}
\hline $\begin{array}{c}\text { Neural Network } \\
\text { Hierarchy }\end{array}$ & Training Error & Test Error & Validation Error & $\begin{array}{c}\text { Deviation of Calculated } \\
\text { Values from Actual Ones, \% }\end{array}$ \\
\hline MLP 5-8-4-1 & 0.0003 & 0.0008 & 0.0006 & 1.7 \\
\hline
\end{tabular}

The adequacy of the constructed neural network was confirmed by the fact that the deviation of the calculated values of the resulting indicator, obtained using the constructed model, from the actual ones does not exceed $5 \%$, with the training, test, and validation errors not exceeding 0.0008 . Determined coefficients of elasticity of the dependent variable on the independent variable indicate that:

When indicator EAP_GR grows by $1 \%$ as compared to the 2019 value, the integral indicator of the efficacy increases by $1.38 \%$;

When indicator Empl_GR grows by 1\% as compared to the 2019 value, the integral indicator of the efficacy increases by $1.76 \%$;

When indicator Unempl_GR grows by 1\% as compared to the 2019 value, the integral indicator of the efficacy decreases by $1.93 \%$;

When indicator Empl_R grows by $1 \%$ as compared to the 2019 value, the integral indicator of the efficacy increases by $1.58 \%$;

When indicator Real_Wage_GR grows by $1 \%$ as compared to the 2019 value, the integral indicator of the efficacy increases by $1.83 \%$.

To determine the prospects for the development of solidarity and accumulative pension systems, the authors used the dynamics of the values of EAP_GR, Empl_GR, Unempl_GR,Empl_R, and Real_Wage_GR as a whole for the Republic during 2002-2019. Descriptive characteristics of indicators for this period are given in Table 6. The transition from the regional level of analysis (which was used to build an integral model for assessing the pension system efficacy and a model for forecasting its efficacy) to the Republican level (which was used to obtain predicted values for the pension system efficacy indicator) was conditioned by the need to determine the general development prospects for the pension system in Kazakhstan.

Table 6. Descriptive characteristics of the indicators of the Kazakhstani pension system efficacy for 2002-2019.

\begin{tabular}{cccccc}
\hline \multirow{2}{*}{ Indicator } & \multicolumn{5}{c}{ Descriptive Characteristics } \\
\cline { 2 - 6 } & $\boldsymbol{Z}_{\text {min }}$ & $\boldsymbol{Z}_{\text {max }}$ & $\mathbf{Z}_{\text {av }}$ & $V$ & GR $_{\text {av }}$ \\
\hline EAP_GR & 0.989 & 1.035 & 1.012 & $1.2 \%$ & 1.0012 \\
\hline Empl_GR & 0.991 & 1.041 & 1.015 & $1.4 \%$ & 1.0005 \\
\hline Unempl_GR & 0.885 & 1.005 & 0.969 & $3.6 \%$ & 1.0068 \\
\hline Empl_R & 0.907 & 0.952 & 0.937 & $1.6 \%$ & 1.0029 \\
\hline Real_Wage_GR & 0.977 & 1.091 & 1.028 & $4.1 \%$ & 1.0023 \\
\hline
\end{tabular}

Note: $Z_{\min }$-the minimum value of the indicator for the period of 2002-2019; $Z_{\max }$-the maximum value of the indicator; $Z_{a v}$ 一 the arithmetic mean of the indicator; $V$ - the coefficient of variation of the indicator, $\%$; $G R_{a v}$-the average chain growth rate of the indicator.

During 2002-2019, values of indicators EAP_GR, Empl_GR, Unempl_GR, Empl_R, and Real_Wage_GR were at a stable level, as evidenced by the coefficient of variation of $1.2-4.1 \%$. The geometric average growth rate of the indicators for this period was 1.0012 for EAP_GR, 1.0005 for Empl_GR, 1.0068 for Unempl_GR, 1.0029 for Empl_R, and 1.0023 for Real_Wage_GR.

Average growth rates of indicators $\left(G R_{a v}\right)$ were used as the basis for forecasting the pension system efficacy. If the current trends in the labor market development are observed, in the future the indicator of the Kazakhstani pension system efficacy will decrease by $0.20 \%$ annually.

The growth in the number of the unemployed exerts the main destabilizing effect on the pension system efficacy. The average increase in this indicator for the period 2002-2019 is $0.68 \%$. A rising 
unemployment rate leads to a decrease in the potential base for pension payments. A decrease in the total amount of wages received (due to the lack of wages for the unemployed) results in a decrease in the amount of income tax as a source of budget replenishment and basic pension payments, a decrease in the amount of mandatory contributions under the accumulative system, and reduced opportunities for increasing voluntary contributions. In addition, unemployment leads to higher state payments being needed, which creates an additional burden on the budget. Therefore, further growth of the unemployment index by $0.68 \%$ leads to a decrease in the integral indicator of the pension system efficacy by $1.31 \%$.

The negative impact of unemployment growth on the pension system efficacy is compensated for by the growth of the economically active population (a growth of the integral indicator by $0.16 \%$ ), the employment rate (a growth of the integral indicator by $0.09 \%$ ), the employment level (a growth of the integral indicator by $0.45 \%$ ), and real wages (a growth of the integral indicator by $0.42 \%$ ).

\section{Discussion}

An approach to the economic and mathematical substantiation of target indicators is needed for the participation of solidarity and accumulative pension systems. This approach is based on determining the impact of part of the solidarity and accumulative systems on the integral efficacy of the pension system. The methodology of the current and prospective assessment of this efficacy as exemplified by this Kazakhstan case study reflects the macroeconomic level of the pension provision efficacy. It assumes an integral assessment rather than an assessment by particular indicators, in contrast to the existing techniques used $[6,7,20]$.

The method for determining the weight factors of indicators in the model of the current assessment makes it possible to combine statistical and expert characteristics of indicator significance, which ensures high accuracy of the assessment results. This approach enables assessing the synthetic efficacy of the pension system rather than the impact of pension provision on economic activity in the country from the viewpoint of the adequacy of pension payments in relation to the pensioners' standard of living [20]. Thus, the pension system efficacy is perceived as a macroeconomic category and, with regard to specific conditions, it is substantiated as the ratio between the pension system adequacy (including protection against poverty and consumption smoothing) and its cost, pension costs, and negative effects on the economy, especially in the labor market.

Taking into account the different opinions of scholars as to pension provision models, the presented methodology for determining the pension system efficacy made it possible to consider the peculiarities and development trends of the pension system in the country. It ensures the development of a flexible component structure of pension provision, focused on specific goals, provides consideration of specific conditions, and assumes the identification of criteria by which the pension reform will be compared with the existing schemes. The presented empirical calculations make it possible to compare solidarity and accumulative pension systems within one country, and quantitatively assess the time intervals in which one system is preferable to the other, as well as the efficiency and proportionality of their combination. Overall efficacy is significant when comparing pension systems because it is synthetic and takes into account many aspects of the pension system operation.

The results of the study enabled us to conclude that for Kazakhstan, it is advisable to employ a mixed model of the pension system (solidarity + accumulative) at the current stage of development. At the same time, there is an urgent need to increase the accumulative part of the pension system to $79.5 \%$ in the structure of financing pension payments, which will ensure maximum efficacy of the pension system at the macroeconomic level. According to the Labor Code of the Republic of Kazakhstan and the Law "On Pension Provision in the Republic of Kazakhstan" [8], persons of working age include citizens aged 16-58 years (women) and 16-63 years (men) with an envisioned increase in the working age for women to 63 years until 2027. Considering these amendments in legislation, the maximum employment duration for pension provision by 2027 will be 47 years. The real rate of return on UAPF deposits is $2.5 \%$ [10]. Under these conditions, taking into account the annuity scheme 
for calculating interest rate on pension contributions, the frequency of deductions and interest charges once a year, calculated for the optimal participation of the accumulative system (79.5\%) to ensure a replacement rate of $40 \%$, as recommended by the International Labor Organization, the annual rate of contributions to the UAPF must be at least $17.05 \%$ of an average person's wages. With the employment duration of 45 years it should be $17.55 \%$; in the case of 40 years' employment duration it should amount to $18.87 \%$, and it should be $20.26 \%$ in the case of 35 years of work experience. Under the current circumstances of the labor market development in Kazakhstan, this is only possible with the implementation of radical reforms based on taking the following measures: introducing flexible rates of pension contributions to the UAPF, providing economic substantiation of minimum pension guaranteed by the state, developing an effective mechanism for declaring the income and expenses of the population, ensuring the coverage of the working population make adequate contributions to the pension system up to a level of at least $90 \%$ of the efficient level, etc. The practical implementation of this system of measures will contribute to the financial stability of the pension system in Kazakhstan, as well as the adequacy of pension payments for a decent standard of living at the retirement age.

It should be noted that the deep problems and reform of the pension system in Kazakhstan and the rapid acceleration of changes in the existing economic conditions complicate the real achievement of its effectiveness in practice. In view of this, attention should be focused on the need for innovative development of funded pension provision in the country [54,55]. In view of the functioning of the pension system of Kazakhstan in conditions of fundamental and institutional problems that cannot be quickly resolved, the need to use an open innovation strategy has been determined. It is open innovations that make it possible not to waste resources on expensive $R \& D$, but instead to concentrate on the most profitable innovative projects to achieve synergy of efficiency in the implementation of pension reform in the country. For the Kazakhstani realities of the pension system, this can be especially relevant in connection with the need to retain promising students, graduate students, and scientists. Since open innovations take a variety of forms, the main effect of their implementation in the pension system of Kazakhstan should be based on innovative start-ups for the implementation of business models of the future, ensuring they can achieve financial security for life and protecting the value of participants' pension contributions from market fluctuations by transferring them to funds with a lower level of risk as we approach the date of retirement. In modern conditions, the pension system is entering a new stage of innovation, when the sources of the innovative potential of pension provision are outside this system [55]. Open innovation strategies based on the principles of individual decision-making and personal lifestyles can also help diversify the pension investments of the population in appropriate funds in order to best generate an appropriate level of pension benefits when people retire.

The possibilities of using a predictive model for assessing the pension system efficacy in Kazakhstan are limited because of the lack of sufficient data. This does not allow for a more accurate forecast of the development dynamics of the accumulative pension system for a long period. The models are constructed based on data for Kazakhstan; in this regard, certain targets for the development of accumulative and solidarity pension systems (their ratio in shares) are applicable only for Kazakhstan. In addition, labor market indicators should be considered as relevant to the entire pension system, as not only public, but also private schemes can influence decisions to leave the labor force. For this reason, the analysis of the efficacy carried out using the proposed approach may require further and deeper study of the pension provision efficacy. This research can be treated as a contribution to the discussion on the reform of the pension system in the former communist countries belonging to the Soviet Union. These countries struggle with many serious social problems, including corruption, as indicated by Transparency International. From such a perspective, this article seems useful. However, the proposed methodology is universal and can be used in assessing the pension system efficacy and determining the prospects for its development for other countries that use solidarity and accumulative pension systems. 


\section{Conclusions}

Based on this research, the following conclusions were drawn. Under conditions of a low birth rate, increased life expectancy, low income of the population, and an extensive shadow economy, the functioning of the synthetic model for pension provision seems appropriate for the current pension system of Kazakhstan, with the accumulative model dominating in the structure of pension provision. Since the labor market is determined to be one of the fundamental factors of the Kazakhstani pension system's efficacy, the share of the accumulative model in the structure of the pension system should be increased to $79.5 \%$, while the annual rate of dedications to the UAPF should be at least $17.05 \%$ of average wages. This will ensure maximum efficacy of the pension system on a macroeconomic scale. If the current trends in the labor market development persist, then the indicator of the Kazakhstani pension system efficacy will annually decrease by $0.20 \%$. This decrease would be caused primarily by the increasing unemployment rate.

Author Contributions: Conceptualization, G.A.J.; Data curation, G.A.J.; Formal analysis, M.D.Z.; Investigation, G.A.J.; Methodology, G.A.J. and M.D.Z.; Project administration, G.A.J.; Resources, M.D.Z.; Software, M.D.Z.; Supervision, G.A.J.; Validation, G.A.J. and M.D.Z.; Visualization, M.D.Z.; Writing一original draft, G.A.J. and M.D.Z.; Writing - review \& editing, G.A.J. and M.D.Z. All authors have read and agreed to the published version of the manuscript.

Funding: This research received no external funding.

Conflicts of Interest: The authors declare no conflict of interest.

\section{References}

1. Nishiyama, S. The joint labor supply decision of married couples and the U.S. Social Security pension system. Rev. Econ. Dyn. 2019, 31, 277-304. [CrossRef]

2. Romp, W.; Beetsma, R. Sustainability of pension systems with voluntary participation. Insur. Math. Econ. 2020, 93, 125-140. [CrossRef]

3. Attias, A.; Arezzo, M.F.; Pianese, A.; Varga, Z. A comparison of two legislative approaches to the solidarity pension system in terms of adequacy. The Italian case. Insur. Math. Econ. 2016, 68, 203-211. [CrossRef]

4. Fenge, R.; Peglow, F. Decomposition of demographic effects on the German pension system. J. Econ. Ageing 2018, 12, 61-76. [CrossRef]

5. Order of the Prime Minister of the Republic of Kazakhstan dated March 19, 1997 N 70-r. On the Concept of Pension System Reforming in the Republic of Kazakhstan. 1997. Available online: https://tengrinews.kz/zakon/ pravitelstvo_respubliki_kazahstan_premer_ministr_rk/sotsialnoe_obespechenie/id-R970000070/ (accessed on 3 August 2020).

6. Cerda, R.A. The Chilean pension reform: A model to follow? J. Policy Model. 2008, 30, 541-558. [CrossRef]

7. Grishchenko, N. Pensions after Pension Reforms: A Comparative Analysis of Belarus, Kazakhstan, and Russia. Procedia Econ. Financ. 2016, 36, 3-9. [CrossRef]

8. Law of the Republic of Kazakhstan Dated June 21, 2013 No. 105-V (with Amendments and Supplements as of 07.07.2020). On Pension Provision in the Republic of Kazakhstan. 2013. Available online: https: //online.zakon.kz/document/?doc_id=31408637\#pos=3;-106 (accessed on 3 August 2020).

9. Beetsma, R.M.W.J.; Romp, W.E.; Vos, S.J. Voluntary participation and intergenerational risk sharing in a funded pension system. Eur. Econ. Rev. 2012, 56, 1310-1324. [CrossRef]

10. UAPF. 2020. Available online: https://www.enpf.kz/en/ (accessed on 1 August 2020).

11. Ministry of Finance of the Republic of Kazakhstan. 2020. Available online: https://www.gov.kz/memleket/ entities/minfin/activities/448?lang=ru (accessed on 1 August 2020).

12. Forbes. Why the Pension System of Kazakhstan Is Good for the Poor, But Bad for the Middle Class. 2020. Available online: https://forbes.kz//process/expertise/pochemu_pensionnaya_sistema_rk_horosha_dlya_ bednyih_no_ploha_dlya_srednego_klassa/? (accessed on 30 July 2020).

13. OECD. Net Pension Replacement Rates. 2020. Available online: https://data.oecd.org/pension/net-pensionreplacement-rates.htm (accessed on 3 August 2020). 
14. Smaiyl, M. One in Five will be over 60 Years Old. What Problems Await the Pension System of Kazakhstan. Tengrinews. 2020. Available online: https://tengrinews.kz/kazakhstan_news/kajdyiy-pyatyiy-starshe-60-letkakie-problemyi-jdut-389977/ (accessed on 1 August 2020).

15. Committee on Statistics of the Ministry of National Economy of the Republic of Kazakhstan. 2020. Available online: https://stat.gov.kz/ (accessed on 1 August 2020).

16. National Bank of Kazakhstan. Daily Official (Market) Foreign Exchange Rates. 2020. Available online: https://nationalbank.kz/en/exchangerates/ezhednevnye-oficialnye-rynochnye-kursy-valyut (accessed on 4 November 2020).

17. Koutronasa, E.; Yew, S.Y. Considerations in pension reforms: A review of the challenges to sustainability and distributive impartiality. Malays. J. Econ. Stud. 2017, 54, 159-177. [CrossRef]

18. Amaglobeli, D.; Chai, H.; Dabla-Norris, E.; Dybczak, K.; Soto, M.; Tieman, A.F. The Future of Saving: The Role of Pension System Design in an Aging World; IMF Staff Discussion Note. SDN/19/01; International Monetary Fund: Washington, WA, USA, 2019.

19. Decree of the President of the Republic of Kazakhstan Dated June 18, 2014 No 841. On the Concept of Further Modernization of the Pension System in the Republic of Kazakhstan until 2030. 2014. Available online: https://cdb.kz/sistema/pravovaya-baza/o-kontseptsii-dalneyshey-modernizatsii-pensionnoysistemy-respubliki-kazakhstan-do-2030-goda/ (accessed on 3 August 2020).

20. Bernal, N.; Olivera, J. Choice of pension management fees and effects on pension wealth. J. Econ. Behav. Organ. 2020, 176, 539-568. [CrossRef]

21. Chybalski, F. The Multidimensional Efficiency of Pension System: Definition and Measurement in Cross-Country Studies. Soc. Indic. Res. 2016, 128, 15-34. [CrossRef]

22. Roman, M.D.; Toma, G.C.; Tuchiluş, G. Efficiency of Pension Systems in the EU Countries. Rom. J. Econ. Forecast. 2018, XXI, 161-173.

23. Bossler, M. The efficiency wage effect of employer provided occupational pensions. J. Eur. Labor Stud. 2015, 4, 8. [CrossRef]

24. Blau, D.M. Pensions, household saving, and welfare: A dynamic analysis of crowd out. Quant. Econ. 2016, 7, 193-224. [CrossRef]

25. Hu, W. Policy effects on transitional welfare in an overlapping generations model: A solidarity pension reconsidered. Econ. Model. 2019, 81, 40-48. [CrossRef]

26. Barr, N.; Diamond, P. The economics of pensions. Oxf. Rev. Econ. Policy 2006, 22, 15-39. [CrossRef]

27. Makarski, K.; Hagemejer, J.; Tyrowicz, J. Analyzing the Efficiency of Pension Reform: The Role of the Welfare Effects of Fiscal Closures. Macroecon. Dyn. 2017, 21, 1205-1234. [CrossRef]

28. O'Dea, C. Insurance, Efficiency and the Design of Public Pensions. 2017. Available online: https://economics. stanford.edu/sites/g/files/sbiybj9386/f/odea_jmp.pdf (accessed on 2 August 2020).

29. Ang, J.B. Household Saving Behaviour in an Extended Life Cycle Model: A Comparative Study of China and India. J. Dev. Stud. 2009, 45, 1344-1359. [CrossRef]

30. Chybalski, F.; Marcinkiewicz, E. The Replacement Rate: An Imperfect Indicator of Pension Adequacy in Cross-Country Analyses. Soc. Indic. Res. 2016, 126, 99-117. [CrossRef]

31. Aguiar, M.; Hurst, E. Permanent-Income Hypothesis; The New Palgrave Dictionary of Economics; Palgrave Macmillan: London, UK, 2008.

32. Zhao, Q.; Li, Z.; Chen, T. The Impact of Public Pension on Household Consumption: Evidence from China's Survey Data. Sustainability 2016, 8, 890. [CrossRef]

33. Vaillancourt, F.; Lammam, C.; Herzog, I.; Ebrahimi, P. Compulsory Government Pensions vs Private Savings. The Effect of Previous Expansion to the Canada Pension Plan. 2015. Available online: https://www. fraserinstitute.org/sites/default/files/compulsory-government-pensions-vs-private-savings.pdf (accessed on 3 August 2020).

34. Shin, I. Could pension system make us happier? Cogent Econ. Financ. 2018, 6, 1452342. [CrossRef]

35. Góra, M. Retirement Decisions, Benefits and the Neutrality of Pension Systems. ENEPRI research report no. 51. 2008. Available online: https://www.files.ethz.ch/isn/93987/RR\%20051.pdf (accessed on 1 August 2020).

36. OECD. Pension-system Typology; Pensions at a Glance 2005: Public Policies across OECD Countries. OECD Publishing: Paris, France, 2006. Available online: https://www.oecd-ilibrary. org/docserver/pension_glance-2005-3-en.pdf?expires=1596746569\&id=id\&accname=guest\&checksum= DC27B3A7B09972DD0ECC7B63B3FFD5F5 (accessed on 2 August 2020). 
37. Aleskerova, Y.; Saкovska, O.; Didenko, Y. Analysis of the Essence of Pension Insurance and Its Place in the System of Social Protection of the Population. Balt. J. Econ. Stud. 2020, 6, 9-16. [CrossRef]

38. Wang, P.; Zhang, M.; Shand, R.; Howell, K.E. Retirement, Pension Systems and Models of Pension Systems. Economics Working Paper No. 1402. 2014. Available online: https://www.plymouth.ac.uk/uploads/ production/document/path/8/8845/models_of_pension_systems_wp.pdf (accessed on 3 August 2020).

39. OECD. Recent Pension Reforms and Their Distributional Impact; Pensions at a Glance 2013: OECD and G20 Indicators; OECD Publishing: Paris, France, 2013.

40. Zhu, H.; Walker, A. Pension system reform in China: Who gets what pensions? Soc. Policy Adm. 2018, 52, 1410-1424. [CrossRef]

41. Mavlutova, I.; Titova, S.; Fomins, A. Pension System in Changing Economic Environment: Case of Latvia. Procedia Econ. Financ. 2016, 39, 219-228. [CrossRef]

42. Menke, W. Factor Analysis. Geophysical Data Analysis, 4th ed.; Academic Press: New York, NY, USA, 2018; pp. 207-222.

43. Malema, K. Factor Analysis of Challenges Experienced with Regard to Implementation of the Pension Act of 2011 in Malawi. IOSR J. Bus. Manag. 2019, 21, 38-46. [CrossRef]

44. Jureviciene, D.; Volkova, M. Evaluation of the 3rd pillar pension funds in Lithuania. J. Bus. Econ. Manag. 2014, 15. [CrossRef]

45. Hanea, A.; McBride, M.; Burgman, M.; Wintle, B. The Value of Performance Weights and Discussion in Aggregated Expert Judgments. Risk Anal. 2018, 38. [CrossRef]

46. Holzmann, R.; Hinz, R.P.; Dorfman, M. Pension Systems and Reform Conceptual Framework; The World Bank. SP Discussion Paper No. 0824; The World Bank: Washington, WA, USA, 2008.

47. Zhao, Q.; Mi, H. Evaluation on the Sustainability of Urban Public Pension System in China. Sustainability 2019, 11, 1418. [CrossRef]

48. Rajevska, O. Theoretical Old-Age Pension Benefits and Replacement Rates in the Baltic States: A Retrospective Simulation. Econ. Bus. 2016, 28, 13-19. [CrossRef]

49. Assessment of the Pension System Efficacy. 2020. Available online: https://docs.google.com/forms/d/e/ 1FAIpQLSf4Emv3O0a9lhdgC_Nr9U5ToVBkYvkm8YHuCM6F8OgkR4n25Q/viewform?vc=0\&c=0\&w=1\& flr $=0$ (accessed on 3 August 2020).

50. Ceni, R. Pension schemes and labor supply in the formal and informal sector. IZA J. Labor Policy 2017, 6, 8. [CrossRef]

51. Geyer, J.; Haan, P.; Hammerschmid, A.; Peters, M. Labor Market and Distributional Effects of an Increase in the Retirement Age. IZA Discussion Papers 1741. 2018. Available online: https:/www.diw.de/documents/ publikationen/73/diw_01.c.592820.de/dp1741.pdf (accessed on 3 August 2020).

52. Hernæs, E.; Markussen, S.; Piggott, J.; Røed, K. Pension reform and labor supply. J. Public Econ. 2016, 142, 39-55. [CrossRef]

53. Haan, P.; Prowse, V. Optimal Social Assistance and Unemployment Insurance in a Life-Cycle Model of Family Labor Supply and Savings; IZA Discussion Paper 8980; German Institute for Economic Research: Berlin, Germany, 2015.

54. Lee, K.; Jung, K. Exploring institutional reform of Korean civil service pension: Advocacy coalition framework, policy knowledge and social innovation. J. Open Innov. Technol. Mark. Complex. 2018, 4, 14. [CrossRef]

55. Didenko, N.I.; Romashkina, G.F.; Skripnuk, D.F.; Kulik, S.V. Dynamics of Trust in Institutions, the Legitimacy of the Social Order, and Social Open Innovation. J. Open Innov. Technol. Mark. Complex. 2020, 6, 111. [CrossRef]

Publisher's Note: MDPI stays neutral with regard to jurisdictional claims in published maps and institutional affiliations.

(C) 2020 by the authors. Licensee MDPI, Basel, Switzerland. This article is an open access article distributed under the terms and conditions of the Creative Commons Attribution (CC BY) license (http://creativecommons.org/licenses/by/4.0/). 